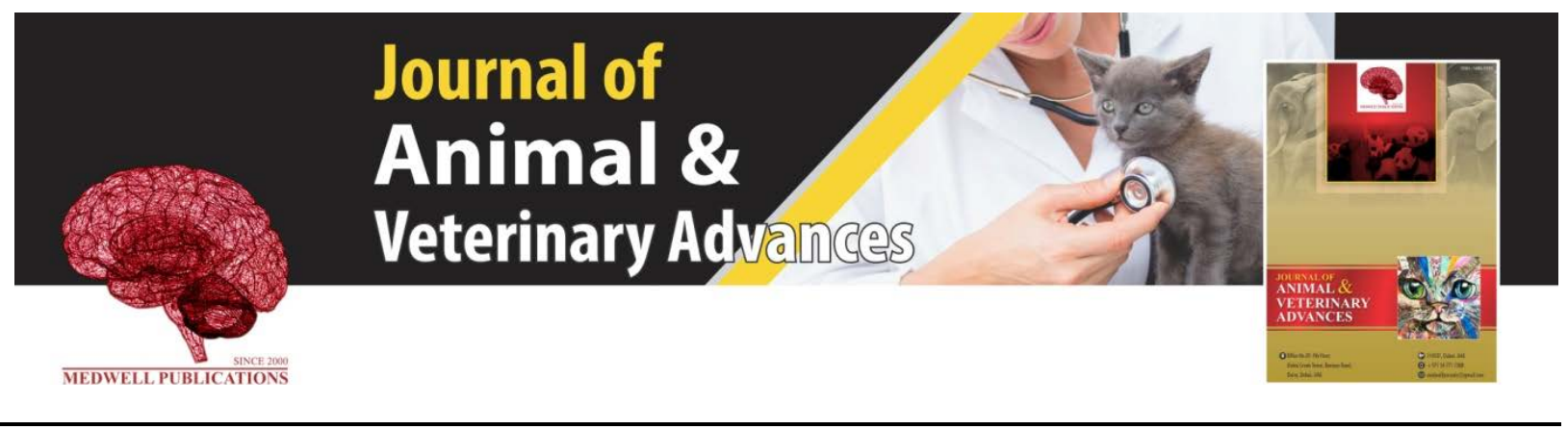

\title{
Evaluation of Body Condition Score in Ankole Cattle in Nyagatare District of Rwanda
}

${ }^{1}$ Nadine Kabasingiza, ${ }^{1}$ Gilbert Mutoni and ${ }^{2}$ Mupenzi Mutimura

${ }^{1}$ Department of Animal Sciences and Veterinary Medicine (CAVM), College of Agriculture, University of Rwanda, Nyagatare Campus, P.O. Box 57 Nyagatare, Rwanda

${ }^{2}$ Rwanda Agriculture and Animal Resources Development Board, P.O. Box 5016 Kigali, Rwanda

Key words: Longevity, disease prevalence, physical appearance, reproduction, production performances

Corresponding Author:

Nadine Kabasingiza

Department of Animal Sciences and Veterinary Medicine (CAVM), College of Agriculture, University of Rwanda, Nyagatare Campus, P.O. Box 57 Nyagatare, Rwanda

Page No.: 43-46

Volume: 19, Issue 4, 2020

ISSN: 1680-5593

Journal of Animal and Veterinary Advances

Copy Right: Medwell Publications
Abstract: Body Condition Score (BCS) is a very important management tool in livestock particularly because of its association with health, reproduction and production performances in cattle. However, there is a little information on Body Condition Score (BCS) of Ankole cattle and their effect on reproduction, production and longevity. The objective of the study was to evaluate body condition score and its influence on production and reproduction performances as well as health status of Ankole cows in Nyagat are district of Rwanda. Based on the sampling frame, 60 Ankole cattle were evaluated and primary data were collected through visual, touch and feel on the external part of the body while the existing records were used as secondary data. Results showed that BCS had an influence on longevity, disease prevalence, physical appearance, production and reproduction performances in Ankole cows. High percentage (25\%) of Ankole cows had a body condition score of three. These cows had normal reproduction performance compared to the rest of cows. The healthiest cows were found to be in the BCS of 3-5. This means that better BSC for disease prevalence was $\geq 3$. It is suggested that farmers should use the BCS as a management tool to improved productivity of Ankole cows.

\section{INTRODUCTION}

Cattle are the most important livestock species in the African continent and in many parts of the world. Ankole cattle in particular exist in several countries of Eastern Africa, where their different eco types are generally, identified as Ankole. Among the eco types, Ankole cattle are found in Burundi, Rwanda, tribe of Bashi in Democratic Republic of Congo, tribe of Bahima or Nsagallain Uganda and Tanzania ${ }^{[1]}$. There exist different methods to evaluate performances of cattle, especially, reproduction, production and health. Body condition score is one of the methods. Body Condition Score (BCS) is an indicator of welfare of an animal on the maintenance and production, especially, energy balance as well as relationship between feeding and production performance within a herd ${ }^{[2]}$. However, animal breeders are also interested in the body condition score. This is because the BCS is used to select a dairy cow which will produces high milk in an efficient way for a long period without problems ${ }^{[3]}$. The BCS could indicate the health of cows as well. 
Furthermore, BCS is a subjective assessment of the amount of fat or energy kept in the body of a cow. The BCS method consists of scoring a cow which is a simple visual assessment of some parts of a cow where adipose tissues are more accumulated ${ }^{[2]}$. The BSC has become a simple, yet robust tool to leverage feeding and management practices, especially in maximising milk production, reducing metabolic disorders in early lactation (ketosis, fatty cow syndrome) while minimising reproductive problems. Majority of researches conducted on cow body condition had the objective to show the ideal condition for optimum production of the cow. This is mostly linking condition at calving with milking potential or fertility but equally important was to establish the correct score for ease of calving. According to Hirwa et al. ${ }^{[4]}$, the body condition score and body weight effect on dystocia and stillbirths and consequently, effect on post calving performance. Therefore, BCS is very important management tool in livestock generally because of its association with production performances, health status and reproduction performances. The objective of the study was to evaluate the body condition score and its influence on production and reproduction performances as well as health status of Ankole cows in Nyagatare district of Rwanda.

\section{MATERIALS AND METHODS}

Description of the study area: The research was conducted at Karama stationof Rwanda Agriculture and Animal Resources Development Board (RAB) in Nyagatare district, Eastern province of Rwanda. The farm covers an area of 250 ha. It is a farm in which Ankole cattle and goats are being reared for Animal Genetic Resources (AnGR) conservation. The farm is also a centre of testing and evaluation of various forages such as Chloris Gayana, Brachiaria sp. and some of legumes like Desmodium sp., Canavalia sp. According to the seasonal changesand variability, Karama experiences low rain (average of $826 \mathrm{~mm}$ per annum) and high temperatures (average of $26.5^{\circ} \mathrm{C}$ per annum).

Study design and data collection: Among Ankole cattle that were raised at Karama farm, 60 adult female cows were selected to be experimental animals because they were producing milk and their reproduction performances were developed and ready to be inseminated, conceive calve and produce milk. The primary data were the results of observation and measurement taken directly from cattle at the farm while secondary data mainly live weight and milk were taken from existing recorded data provided by Karama farm of RAB-Nyagatare station. Age and number of lactation were also the secondary data taken based on the existing records.
Data on physical appearance were the results of visual on the external part of the body which came up with an idea of grouping them into five categories of too thin, thin, middle, fat and too fat cows. In addition, data on disease prevalence were also recorded by considering cows which were supposed to be all the time to suffer as those that were treated for different diseases $>7$ times per month and those that were not all the time to suffer as those that were treated for different diseases two to six times per month. Furthermore, Ankole cows that were hardly to suffer were considered as those that were treated zero to one time per month.

Furthermore, data on reproduction performance were taken by grouping cows into difficult, normal and very difficult as a mean of expressing what happened during the artificial insemination and calving processes for selected cows. In addition, selected Ankole cows were those that had difficulty in conception, especially, after two or three times of artificial insemination. Also, time they aborted after conception or giving still birth. Cows that calved, produced few milk thus, unable to feed their calves until the weaning period. Cows that were selected to be normal were those that conceived at one or more time of artificial insemination and they did not have difficulties during calving. They had also a good mothering ability such as production of enough milk compared to other cows within different scores.

Both primary and secondary data were used. Primary data were recorded directly on the farm while secondary data were taken from farm books recorded for the age, number of lactation, disease prevalence and reproduction performances recorded until May, 2019. For the primary data, information on production was recorded, Body Condition Score (BCS), a score from 1-5 was developed. For cows in milk, single milk was record in the morning. The number of time a lactating cow was milked was also recorded.

Data analysis: To determine the trends and relationship among variables, collected data were recorded, entered, verified using Microsoft excel and analysed using SPSS v.22 (SPSS, 2013) and results presented using tables.

\section{RESULTS AND DISCUSSION}

Body condition score of Ankole cows: Results showed that majority of Ankore cows (25\%) were in body condition score 3 , followed by score 4 (23.3\% of cows) and 2 (21.6\% of cows; Table 1$)$.

Table 1: Scoring body condition of Ankole cows in the study area

\begin{tabular}{lcc}
\hline BCS & No. of cows & Percentage \\
\hline 1 & 7 & 11.7 \\
2 & 13 & 21.6 \\
3 & 15 & 25.0 \\
4 & 14 & 23.3 \\
5 & 11 & 18.3 \\
Total & 60 & 100.0 \\
\hline
\end{tabular}


J. Anim. Vet. Adv., 19 (4): 43-46, 2020

Table 2: Evaluation of BCS on body weight, age, milk production and number of lactation of Ankole cows at Karama farm

\begin{tabular}{|c|c|c|c|c|c|c|}
\hline \multirow[b]{2}{*}{ Units } & \multicolumn{5}{|c|}{ Body condition score } & \multirow[b]{2}{*}{ p-values } \\
\hline & 1 & 2 & 3 & 4 & 5 & \\
\hline $\mathrm{BW}(\mathrm{kg})$ & $394.5 \pm 63 c$ & $384.8 \pm 44^{\mathrm{c}}$ & $460.7 \pm 53.7^{b}$ & $463.3 \pm 92.7^{b}$ & $542.4 \pm 86^{\mathrm{a}}$ & $<0.000$ \\
\hline Age (Year) & $5.0 \pm 1^{b}$ & $5.2 \pm 1.3^{\mathrm{b}}$ & $7.03 \pm 1.5^{\mathrm{a}}$ & $5.1 \pm 1.9^{\mathrm{b}}$ & $6.1 \pm 1.9^{\mathrm{ab}}$ & 0.014 \\
\hline MP (Litre) & $0.3 \pm 0.6^{\mathrm{a}}$ & $0.50 \pm 0.7^{\mathrm{a}}$ & $0.9 \pm 0.6^{\mathrm{a}}$ & $0.8 \pm 0.9^{\mathrm{a}}$ & $0.3 \pm 0.7^{\mathrm{a}}$ & 0.158 \\
\hline NL & $1^{\mathrm{b}}$ & $0.9 \pm 0.3^{\mathrm{b}}$ & $2.2 \pm 1.2^{\mathrm{a}}$ & $0.9 \pm 0.9^{\mathrm{b}}$ & $0.8 \pm 0.8^{\mathrm{b}}$ & $<0.000$ \\
\hline
\end{tabular}

Table 3: Disease prevalence, physical appearance and reproduction performances associated with BCS

\begin{tabular}{|c|c|c|c|c|c|c|c|}
\hline \multirow[b]{2}{*}{ Parameters } & \multirow[b]{2}{*}{ Groups } & \multicolumn{5}{|c|}{ Body condition score } & \multirow[b]{2}{*}{ p-values } \\
\hline & & 1 & 2 & 3 & 4 & 5 & \\
\hline \multirow[t]{3}{*}{ Disease prevalence } & All the time & $7(100 \%)$ & $0(0 \%)$ & $0(0 \%)$ & $0(0 \%)$ & $0(0 \%)$ & $<0.000$ \\
\hline & Not all the time & $0(0 \%)$ & $13(100 \%)$ & $0(0 \%)$ & $0(0 \%)$ & $0(0 \%)$ & \\
\hline & Hardly to suffer & $0(0 \%)$ & $0(0 \%)$ & $15(100 \%)$ & $14(100 \%)$ & $11(100 \%)$ & \\
\hline \multirow{5}{*}{ Physical appearance } & Too thin & $7(100 \%)$ & $0(0 \%)$ & $0(0 \%)$ & $0(0 \%)$ & $0(0 \%)$ & $<0.000$ \\
\hline & Thin & $0(0 \%)$ & $13(100 \%)$ & $0(0 \%)$ & $0(0 \%)$ & $0(0 \%)$ & \\
\hline & Middle & $0(0 \%)$ & $0(0 \%)$ & $15(100 \%)$ & $0(0 \%)$ & $0(0 \%)$ & \\
\hline & Fat & $0(0 \%)$ & $0(0 \%)$ & $0(0 \%)$ & $13(93 \%)$ & $0(0 \%)$ & \\
\hline & Too fat & $0(0 \%)$ & $0(0 \%)$ & $0(0 \%)$ a & $1(7 \%)$ & $11(100 \%)$ & \\
\hline \multirow[t]{3}{*}{ Reproduction performance } & Difficult & $7(100 \%)$ & $13(100 \%)$ & $5(33 \%)$ & $8(57 \%)$ & $1(9 \%)$ & $<0.000$ \\
\hline & Normal & $0(0 \%)$ & $0(0 \%)$ & $10(67 \%)$ & $2(14 \%)$ & $0(0 \%)$ & \\
\hline & Very difficult & $0(0 \%)$ & $0(0 \%)$ & $0(0 \%)$ & $4(29 \%)$ & $10(91 \%)$ & \\
\hline
\end{tabular}

Evaluation of BCS on production performances of Ankole cow: The body condition score significantly differed $(p<0.05)$ between ages, body weight and number of lactation. However, there was no significant difference $(\mathrm{p}>0.05)$ in milk production among cows in different BCS (Table 2).

Effect of BCS on disease prevalence, physical appearance and reproduction: Table 3 shows that disease prevalence, physical appearance and reproduction performances varied across the body condition scores. Generally, cows with BCS 3 had normal reproduction performance compared with the rest of the cows. Also, disease prevalence decreased with the increase of BCS where cows with BCS from 3-5 had no disease (Table 3).

Selected Ankole cows for BCS showed that majority of cows (25\%) was in score 3 . Less percentage $(11.7 \%)$ of cows was in BCS 1.The BCS scale used was from 1-5. This shows that majority of selected Ankole cows were in the normal BSC which is between 2.5 (Thin) and 3.5 (Moderate ${ }^{[2]}$ ). Though majority was in BCS 3 , the production performance was not significant difference compared to other BCS. This might be due feeding which was not considered in this study. Normally, BCS enables as well to control feed intake within a herd ${ }^{[5]}$. Nevertheless, the consistency in BCS changes over milk production and number of lactation could be secluded for cow replacement. Furthermore, the study also revealed that body weight, age and number of lactation were significantly different and the consistency with these aspects could be used for cattle selection ${ }^{[6]}$. Furthermore, the BCS were associated with disease prevalence, physical appearance and reproduction performance. The results on reproduction performance showed that too thin cows and fat cows had poor reproductive performance. Too thin cows often do not show heat or conceive until they start to regain or at least maintain body weight. This is because there exists negative energy balance, especially during the first weeks after calving and thus can create a decline or retard reproductive performance ${ }^{[7]}$. Conversely, afat cow is more susceptible to metabolic problems and infections and thus, more likely to have difficulty at calving time $\mathrm{e}^{[8,7]}$. Considering that the study was conducted during rainy season when the natural pasture was plenty and cows could graze at their time it could be the reason of having significant number of cows in the BCS of 3-5. For better management of a farm, fat cows should be culled from the herd because they might have difficulties of reproduction performances.

\section{CONCLUSION}

The Body Condition Scoring (BCS) is an effective and practical tool that enables easy management in cattle herds including Ankole cows. It has shown to affect production, reproduction and health performances of Ankole cows. The best BCS was found to be score 3 for production and reproduction. In addition, the healthiest cows were found to be in the BCS of 3-5. This means that better BSC for disease prevalence was $\geq 3$. It is concluded that body weight, age, number of calving, physical appearance, disease prevalence and reproduction performances were greatly influenced by BCS. Further, studies should look at the body condition score and its derivatives, feed intake, negative energy balance and metabolic parameters including plasma concentration of insulin in Ankole cows.

\section{ACKNOWLEDGEMENTS}

Researchers are grateful to Nyagatare Research Station of Rwanda Agriculture and Animal Resources 
Development Board (RAB) for allowing us to conduct the study at Karama animal farm. All facilities and supports provided for are well acknowledged.

\section{REFERENCES}

01. Nabasirye, M., D.R. Kugonza and D. Mpairwe, 2012. Population structure and dynamics of Ankole cattle in Uganda: Implications for sustainable utilisation of the breed. Afr. J. Agric. Res., 7: 4819-4829.

02. Klopcic, M., A. Hamoen and J. Bewley, 2011. Body condition scoring of dairy cows. University of Ljubljana, Ljubljana, Slovenia.

03. Galukande, E., H. Mulindwa, M. Wurzinger, A.O. Mwai and J. Solkner, 2008. On-farm comparison of milk production and body condition of purebred Ankole and crossbred Friesian-Ankole cattle in south Western Uganda. Proceedings of the Conference on International Research on Food Security, Natural Resource Management and Rural Development, Tropentag 2008 Vol. 9, October 7-9, 2008, University of Hohenheim, Stuttgart, Germany, pp: 1-4.
04. Hirwa, C.D.A., D.R. Kugonza, T. Murekezi, J.D. Rwemarika and A. Kayitesi et al., 2017. Management and phenotypic features of indigenous cattle in Rwanda. Int. J. Livestock Prod., 8: 95-112.

05. Seefeldt, L. and K. Pfeiffer, 2015. Body condition scoring of beef cattle. University of Wisconsin-Madison, Madison, Wisconsin.

06. Mullins, I.L., C.M. Truman, M.R. Campler, J.M. Bewley and J.H. Costa, 2019. Validation of a commercial automated body condition scoring system on a commercial dairy farm. Anim., Vol. 9,

07. Souissi, W. and R. Bouraoui, 2019. Relationship between Body Condition Score, Milk Yield, Reproduction and Biochemical Parameters in Dairy Cows. In: Lactation in Farm Animals, M'Hamdi, N. (Ed.). IntechOpen, New York, USA., pp: 188-101.

08. Pryce, J.E., M.P. Coffey and G. Simm, 2001. The relationship between body condition score and reproductive performance. J. Dairy Sci., 84: 1508-1515. 